\title{
鉄道通勤における最適フレックスタイムパターンの研究* \\ Study of Patterns for Optimal Flexible Work Hours on Railway Commuting*
}

吉村 充功 ‘ 奥村 誠†

By Mitsunori YOSHIMURA ${ }^{\dagger}$ and Makoto OKUMURA ${ }^{\ddagger}$

\section{1. はじめに}

近年，大都市を中心に通勤混雑の緩和を目的とした各種 の TDM 施策が実施されている。しかし，時間分散型の施 策であるフレックスタイムを見ると, 実際に制度を活用で きる (導入されている) 従業者の割合は $8.1 \%$ (平成 11 年現 在)と低水準にある ${ }^{1)}$. そのため, 行政サイドでも制度の 導入促進を提唱しているが，実際にどの程度まで導入割 合を増やせば社会的に十分なのかどうかはこれまで明ら かにされていない.

本研究では, 大都市圈の主たる交通機関である鉄道通勤 を念頭に, 通勤者, 鉄道企業, 一般企業のそれぞれの主体 にとっての効用を定式化する。さらに，始業時刻を変更す ることで生ずる，業務活動の効率の低下の影響を考慮に入 れ，社会的に最も効率的な各主体の行動パターンを分析す るための理論的なモデルを構築し, 求解する。また, 社会 的に最も望ましい出社・始業・終業・退社の時刻分布パ夕ー ンの例を, 数值計算を用いて示す. 以上の分析から，何割 の通勤者がフレックスタイムを行えば社会的に十分である のかを明らかにするとともに，実際に享受する効用の大き さも明らかにする。

\section{2. フレックスタイム制度の問題と理論的研究の概要}

1990 年代に入り, 交通混雑問題の解決策として, フレッ クスタイムや時差出勤をはじめとする TDM 施策が注目さ れるようになり, その導入が期待されている.しかし，こ れらのソフトな施策のもたらす経済効果についての理論 的な研究はあまり多くないのが現状である。そそのため，各 地において試行的に施策を導入して，実施上の問題点や効 果を明らかにしようとする社会実験が行われるようにな り，その成果が学会などで発表されている2).これらの実 験により，渋滞緩和に大きな効果があることが確かめられ ている.しかしながら, 制度を導入すると生活りズムが合 わなくなるという従業者サイドの問題のほかに，業務上の 効率の低下に対する企業の経営上の心配が多く, 企業が始 業時刻を変更することに同意しないという問題点がある

${ }^{*}$ Key words : TDM, 公共交通運用, 交通制御

†学生員, 工修, 広島大学大学院 工学研究科 ( T739-8527 東広島市 鏡山 1-4-1, TEL\&FAX 0824-24-7849)

正会員, 工博, 広島大学大学院 工学研究科助教授 ( $7739-8527$ 東広 島市鏡山 1-4-1, TEL\&FAX 0824-24-7827)
と報告されている。したがって，これらの制度を分析する 上では企業の業務に与える影響を明らかにし，それを上回 るだけの交通混雑緩和効果があることを示す必要がある。

企業の生産活動は, 他の企業と地理的に近いことによ り「集積の経済性」を受けると言われているが，これと 同様のことが時間的な重なりについても存在すると考え られる.すなわち, 業務上, 自社内の他の部署や関連する 他の企業への問い合わせを行う場合，相手方が業務中でな ければその場で用件を済ませることができず，時間をおい て問い合わせをし直すといったことが生じる。このことか ら，都市の業務活動には互いに労働時間帯の一致性を高め ようとする「時間的集積の経済性」が存在している ${ }^{3), 4)}$. 個々の企業が制度を導入するか否かは，この時間的集積の 経済性の大きさに依存する。

フレックスタイム制度に関連して「時間的集積の経済 性」の効果を明示的に初めて言及したのは Henderson で ある. Henderson は都市において 1 つの企業のみが存在す ると仮定し, フレックスタイム制度下での従業者の通勤時 刻選択行動を分析し, 時間的集積の経済性の高い職種の従 業者はピーク時に通勤し, そうでない従業者はその前後に 分散するという興味深い結果を示している 5),6). しかし， この研究では交通混雑関数に工学的な基礎がそしく, 実証 性に問題があった。

文らはこの点を改良した上で，フレックスタイム制度下 の従業者の通勤時刻選択行動を分析するとともに，その下 で固定始業時刻制度をとる企業とフレックスタイム制度を とる企業の利潤を比較し, フレックスタイム制度導入に関 するインセンティブの分析を行っている7). その結果, フ レックスタイム制度には「ロックイン」効果が存在するた めに, 導入する企業数が自動的に増すことが期待できない ことを示した。

また, 赤松らは単一ボトルネック, 複数ボトルネックを もったそれぞれのケースで, 通勤総不効用が最小となる勤 務開始時刻分布を，利用者均衡条件を制約にもつ最適制御 問題として求解している ${ }^{8)}$. しかし, 勤務開始時刻の変更 による企業の生産性の低下の影響は考慮されていない.

上述した研究はいずれも自動車交通を対象にしており, 大都市圏域の主たる通勤手段である鉄道システムにおい ては適用できない。これまで, 筆者らのグループの一連 の研究では, 鉄道通勤市場の交通行動を理論的に分析で きる均衡論的モデルの構築を行った ${ }^{9)}$. さらに, これを時 
差出勤施策のような複数始業時刻下 ${ }^{10)}$, 労働時間の長さ を従業者が自由に決定できる「スーパーフレックス」制度 下11)のそれぞれにおいて鉄道混雑の緩和効果と業務活動 の効率の低下の影響を考慮できる形に発展させ, 施策の実 現可能性を分析した。本研究でもモデルの構築において, これらの考え方を援用する。

\section{3. 鉄道通勤サービス市場と一般企業の生産活動}

\section{(1) 通勤者の出勤・帰宅不効用のモデル化}

1 つのベッドタウンの中心駅から都心へ直通運転される 1 本の通勤鉄道を考える。ベッドタウンに住む全通勤者が この鉄道を利用し, 従業場所である都心へ通勤していると する.ここで, 自宅からベッドタウンの駅までのアクセス 時間, 都心の駅から会社までのイグレス時間は十分に小さ いとする。

時刻 $t_{g}$ に都心に到着する通勤者の出勤による部分不効 用を $U\left(t_{g}\right)$, 時刻 $t_{r}$ に都心を出発する通勤者の帰宅による 部分不効用を $V\left(t_{r}\right)$ とし, 次式のように列車の混雑度と自 宅を早く出発/遅く帰宅することによるスケジュールコス トの和により定義する。

$$
\begin{aligned}
& U\left(t_{g}\right)=-\left(s\left(t_{g}\right)\right)^{\eta}-c\left\{T-\left(t_{g}-w\right)\right\} \\
& V\left(t_{r}\right)=-\left(r\left(t_{r}\right)\right)^{\eta}-e\left\{\left(t_{r}+w\right)-T\right\}
\end{aligned}
$$

ここで, $s\left(t_{g}\right)$ は時刻 $t_{g}$ に都心に到着する列車の, $r\left(t_{r}\right)$ は 時刻 $t_{r}$ に都心を出発する列車の混雑度を表し, 正数であ る. $\eta$ は混雑度に関する弾力值であり, 正数である. $w$ は 通勤・帰宅所要時間であり, 時刻に関わらず一定と仮定す る. $c>0$ (円/分) は自宅出発時刻が早いことに関する, $e>$ 0 (円/分) は自宅帰宅時刻が遅いことに関するスケジュール コストの勾配を表す。つまり, $c, e$ は時間価值を示す。こ こでは, 簡単化のために出勤時と帰宅時の時間価値は等し く, $c=e$ とする. 人ケジュールコ久トはある基準となる 時刻 $T$ を基準に計測する。

\section{(2) 鉄道企業の輸送力供給のモデル化と時刻別運貨}

時点 $t_{g}$ に都心に到着する通勤者に対して供給される輸 送力を単位時間当りの通勤者数を用いて $u\left(t_{g}\right)$ (人/分), 時 点 $t_{r}$ に都心を出発する通勤者に対して供給される輸送力 を単位時間当りの通勤者数を用いて $v\left(t_{r}\right)$ (人/分) と表す. 本研究では議論を単純化するため, 高密度で運行されて いる路線を想定し, 輸送力を時間軸上の連続関数として 扱う。このとき, 時刻 $t_{g}$ 以前に都心に到着する累積通勤 者数の割合を $m\left(t_{g}\right)$, 時刻 $t_{r}$ 以前に都心を出発する累積通 勤者数の割合を $l\left(t_{r}\right)$ とすると, 次式が成立する.

$$
\begin{aligned}
\dot{m}\left(t_{g}\right) N & =s\left(t_{g}\right) u\left(t_{g}\right) \\
\dot{l}\left(t_{r}\right) N & =r\left(t_{r}\right) v\left(t_{r}\right)
\end{aligned}
$$

ただし $, \dot{m}\left(t_{g}\right)=\mathrm{d} m\left(t_{g}\right) / \mathrm{d} t_{g}, \dot{l}\left(t_{r}\right)=\mathrm{d} l\left(t_{r}\right) / \mathrm{d} t_{r}$ である. $N$ は 総通勤者数であり，定数とする。
鉄道企業の出勤, 帰宅時間帯の輸送費用は, それぞれ各 時点ごとにかかる費用を積み上げたものであり，各時点の 費用はその時点 $t_{g}, t_{r}$ の輸送力 $u\left(t_{g}\right), v\left(t_{r}\right)$ の関数であると 仮定する.よって, 出勤時の輸送費用関数 $T R C_{m}$, 㷌宅時 の輸送費用関数 $T R C_{e}$ をそれぞれ次式により定義する.

$$
\begin{aligned}
T R C_{m} & =\int_{T_{0}}^{T_{2}} \zeta\left(u\left(t_{g}\right)\right)^{\ell} \mathrm{d} t_{g} \\
T R C_{\mathcal{c}} & =\int_{T_{1}+H}^{T_{3}+H} \zeta\left(v\left(t_{r}\right)\right)^{l} \mathrm{~d} t_{r}
\end{aligned}
$$

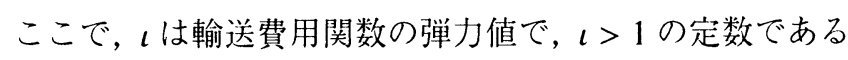
と仮定する。【は輸送費用の比例係数で，正数である。ま た, $T_{0}, T_{2}$ はそれぞれ, すべての通勤者のうち都心へ最も 早く到着する通勤者の時刻, 最も遅く到着する通勤者の時 刻を表し， $T_{1}+H, T_{3}+H$ はそれぞれ，すべての通勤者の うち都心を最も早く出発する通勤者の時刻, 最も遅く出発 する通勤者の時刻を表す。

鉄道企業は総括原価方式に従い，基本運賃を設定してい ると仮定する.すなわち, 各通勤者の出勤にかかる基本運 罆 $R C B_{m}$, 㷌宅にかかる基本運貨 $R C B_{e}$ は次式で表される.

$$
\begin{aligned}
R C B_{m} & =T R C_{m} / N \\
R C B_{e} & =T R C_{e} / N
\end{aligned}
$$

基本運貨とは別に, 最適パターンを実現するための，時 刻別混雑料金を考える. 混雑料金は正・負の值がバランス し，その総和が 0 となるように定義されているとする。す なわち, 出勤時の混雑料金を $\omega_{m}\left(t_{g}\right)$, 㷌宅時の混雑料金を $\omega_{e}\left(t_{r}\right)$ とすると,

$$
\begin{aligned}
& \int_{T_{0}}^{T_{2}} \dot{m}\left(t_{g}\right) N \omega_{m}\left(t_{g}\right) \mathrm{d} t_{g}=0 \\
& \int_{T_{1}+H}^{T_{3}+H} \dot{l}\left(t_{r}\right) N \omega_{e}\left(t_{r}\right) \mathrm{d} t_{r}=0
\end{aligned}
$$

が成立する。したがって, 時刻 $t_{g}$ に出勤する通勤者の出勤 時運賃 $R C_{m}\left(t_{g}\right), t_{r}$ に帰宅する通勤者の帰宅時運賃 $R C_{e}\left(t_{r}\right)$ は次式で表される。

$$
\begin{aligned}
R C_{m}\left(t_{g}\right) & =R C B_{m}+\omega_{m}\left(t_{g}\right) \\
R C_{e}\left(t_{r}\right) & =R C B_{e}+\omega_{e}\left(t_{r}\right)
\end{aligned}
$$

\section{(3) 一般企業の生産活動のモデル化}

すべての一般企業は都心に立地する労働者管理企業で あり，労働力のみを投入し，ニュメレール財を生産する。 このとき, 従業者 1 人あたりの生産額が, そのまま, そ の従業者の賃金として分配されると仮定する。ここでは, 都市内のすべての一般企業は相互に関連があり，業務活動 における時間的集積の経済性が働くと仮定する 5),6).さら に, 都市内には時間的集積の経済性の大きさの等しい産業 のみが存在するとし, 自他社問わず各従業者間で同等の時 間的集積の経済性が働くと仮定する。 
時刻 $t_{w}$ に始業する 1 従業者あたりの 1 日の生産額 $Y\left(t_{w}\right)(=$ 賃金) は次式のように，ある時点に都市内で労㣫 している従業者数を取り入れた瞬間的な生産関数を労働 時間帯 $\left[t_{w}, t_{w}+H\right]$ に渡って積み上げたものとして定義で きる。

$$
Y\left(t_{w}\right)=\int_{t_{w}}^{t_{w}+H} A(\rho(\tau) N)^{\alpha} \mathrm{d} \tau
$$

ここで, $H$ (分) は労働時間であり，すべての従業者で一 定である. $\rho(\tau)$ は時点 $\tau$ に業務を行っている従業者数の 比率を表す．Aは各一般企業の技術水準を表すパラメー 夕， $\alpha$ は時間的集積の経済性の大きさを表すパラメータで, $0<\alpha<1$ であるとし，それぞれ，1 つの都市内では一定 值をとるとする。 $\alpha$ は自動車製造・鉄鋼産業のような装置 依存型の産業が多い都市では大きく、コンサルタント業・ 学術研究機関のような知識集積型産業の多い都市では小 さい值をとる。

$Y\left(t_{w}\right)$ は $\alpha$ が大きい場合には自身の労働時間帯に，より 多くの従業者が労働している方が高くなる。一方， $\alpha$ が小 さい場合には時間的集積の効果が小さく，他の従業者が労 働していなくとも十分な賃金が得られる。

\section{（4）通勤者の総効用}

以上の定式化から, 通勤者 $q$ が最終的に享受する総効 用 $W(q)$ は，以下のように表すことができる.

$$
\begin{aligned}
W(q)= & Y\left(n^{-1}(q)\right)+U\left(m^{-1}(q)\right)+V\left(l^{-1}(q)\right) \\
& -R C_{m}\left(m^{-1}(q)\right)-R C_{e}\left(l^{-1}(q)\right)
\end{aligned}
$$

ここで, $n^{-1}(q), m^{-1}(q), l^{-1}(q)$ はそれぞれ, $t_{w}=n^{-1}(q)$, $t_{g}=m^{-1}(q), t_{r}=l^{-1}(q)$ であり, $n\left(t_{w}\right), m\left(t_{g}\right), l\left(t_{r}\right)$ の逆関数 である。 また, $n\left(t_{w}\right)$ は, 時刻 $t_{w}$ 以前に始業している累積 通勤者数の割合を表す。

各通勤者は，その通勤者にとって有利な状況，すなわち， 式(14)に示した通勤者の効用 $W(q)$ の值が大きくなるよう に出社時刻, 始業 (終業) 時刻, 退社時刻を設定する。 そ のため, 均衡状態においては, 各通勤者の効用は等しく なる．なぜなら，効用が等しくない状態では，効用の低い 通勤者は, 効用の高い通勤者のスケジュールに時刻を变更 することにより，効用の改善が可能であるからである．し たがって, 最終的にはすべての通勤者において, 等効用と なる。

$$
\mathrm{d} W(q) / \mathrm{d} q=0
$$

\section{(5) 社会的厚生水準のモデル化}

政府の目的は, すべての一般企業の総生産額と通勤者の 鉄道通勤による不効用・混雑料金，鉄道企業の輸送費用の 和である「社会的厚生水準」を最大にすることにある．社
会的厚生水準 $S W$ は次式により表される.

$$
\begin{aligned}
S W= & \int_{T_{0}}^{T_{3}+H}\left[\dot{n}(t) N \cdot Y(t)+\dot{m}(t) N\left(U(t)-\omega_{m}(t)\right)\right. \\
& \left.-\zeta u(t)^{\iota}+\dot{l}(t) N\left(V(t)-\omega_{c}(t)\right)-\zeta v(t)^{t}\right] \mathrm{d} t
\end{aligned}
$$

ここで, 式 (16)の右辺第 1 項は総生産額 (=総貢金), 第 2 項は総出勤不効用 · 混雑料金, 第 3 項は総出勤輸送費用, 第 4 項は総帰宅不効用・混雑料金, 第 5 項は総帰宅輸送費 用を表す。

\section{4. フレックスタイム下の最適始業時刻分布の分析}

\section{(1) フレックスタイムの分析の前提}

フレックスタイム下では, 各通勤者は出社時刻・始業時 刻を考える際に，帰宅時のことを考慮する必要が生ずる。 なぜなら，労働時間が一定であるため，始業時刻を変更す れば，その分だけ終業時刻も変化するからである。つまり， 通勤者は 1 日のスケジュールの決定において, 出社時刻, 始業時刻 (終業時刻), 退社時刻を同時に考えることにな る.ここでは, 労働時間が十分に長く, 全員が勤務する時 間帯 $\left[T_{2}, T_{1}+H\right]$ が存在すると仮定する。 なお，最遅始業 時刻は最遅出社時刻 $T_{2}$ に等しく, 最早終業時刻は最早退 社時刻 $T_{1}+H$ に等しいと仮定する。

労働時間はすべての従業者に等しく $H$ (分) なので, 終業 時刻と退社時刻を $-H$ (分) だけずらしても問題の本質が変 わらない.そこで, 分析の簡単化のために終業時刻と退社 時刻を一H(分) だけずらして考える。つまり，累積終業者 数の割合 $1-\rho(t+H)$ を時刻 $t$ 以前に始業している累積始 業者数の割合 $n(t)$ を用いて $1-n(t)$ に，累積退社者数の割 合 $l(t+H)$ を $l(t) に$ に, 帰宅時混雑料金 $\omega_{e}(t+H)$ を $\omega_{e}(t) に$ 变換して取り扱う。

\section{(2) 最適始業時刻分布決定問題の定式化}

3.で定式化したモデルを用いて, 社会的厚生水準 (16)を 最大化する問題を考えると, $s(t), u(t), r(t), v(t), k(t), \omega_{m}(t)$, $\omega_{e}(t)$ を制御变数 $(\equiv z(t))$ とする社会的厚生水準 $S W$ の最 適解決定問題として，以下のように定式化できる.

$$
\begin{aligned}
& \max _{\substack{s(t), u(t), \omega_{m}(t), \omega_{e}(t) \\
r(t) \cdot(t) \cdot(t)<(t)}} S W=\int_{T_{0}}^{T_{3}}\left[\dot{m}(t) N\left(U(t)-\omega_{m}(t)\right)-\zeta u(t)^{t}\right. \\
& +\dot{l}(t) N\left(V(t)-\omega_{e}(t)\right)-\zeta v(t)^{t} \\
& +\dot{n}(t) N \cdot Y(t)] \mathrm{d} t \\
& \text { s.t. } \dot{m}(t)=s(t) u(t) / N \\
& \dot{l}(t)=r(t) v(t) / N \\
& \dot{n}(t) \equiv k(t) / N \\
& \dot{Y}(t)=\left\{\begin{array}{l}
A\left\{(1-n(t))^{\alpha}-n(t)^{\alpha}\right\} N^{\alpha} \\
\text { if }\left(T_{1} \leq t \leq T_{2}\right) \cap(\dot{n}(t) \neq 0) \\
0 \quad \text { if }\left(t<T_{1}, T_{2}<t\right) \cup(\dot{n}(t)=0)
\end{array} .\right. \\
& \mathrm{d} W(q) / \mathrm{d} q=0
\end{aligned}
$$




$$
\begin{gathered}
h_{1}(t) \equiv-l(t) \leq 0 \\
h_{2}(t) \equiv l(t)-n(t) \leq 0 \\
h_{3}(t) \equiv n(t)-m(t) \leq 0 \\
h_{4}(t) \equiv m(t)-1 \leq 0
\end{gathered}
$$

ここで, (17b)-(17e) は状態変数 $x(t)=(m(t), l(t), n(t), Y(t))$ の状態拘束, (17f) は等効用条件を表す。 (17g)-(17j) は $\boldsymbol{x}(t)$ の状態制約条件を表し, 物理的可能条件である。(17k), (171) は状態变数の初期条件, (17m)-(17p) は状態変数の終 端条件を表す。

本問題においては，混雑料金に関する仮定 (9), (10) よ $\eta$, 沉関数 $(17 \mathbf{a})$ 中の混雑料金 $\omega_{m}(t), \omega_{e}(t)$ の総和が 0 に なることに注意すると， $\omega_{m}(t), \omega_{e}(t)$ は等効用条件 (17f $)$ に のみ現れる，そのため，一旦等効用条件 (17f) を外した問 題を考え，事後的にこの条件を満足するように混雑料金を 定めることにより，求解が容易となる。最適制御理論 ${ }^{12)}$ を用いてモデルの求解を行うと, $t \in\left[T_{0}, T_{3}\right]$ において必要 条件を満たす最適軌道 $\boldsymbol{x}(t)=\boldsymbol{x}^{o}(t)$ は, $(17 \mathrm{~g})-(17 \mathrm{j})$ が 0 か 否かの組み合わせにより，a) 全員が一斉始業・終業，b) フ レックスタイムと一斉始業・終業が混在, c) 全員がフレッ クスタイム, の 3 つのパターン (数值例の図-1-図-3 参照) に分類され，それぞれの解は付録 $\mathbf{A}$ に示すように解析的 に求められる。

\section{5. 数值計算例}

\section{(1) 最適軌道の数值例}

時間的集積の経済性の大きさを表す $\alpha$ は産業によって 異なる。 そこで, $\alpha$ の值を变化させ，始業時刻分布の最適 解に代入し，その形状を示す。また，そのパターンを実現 するための混雑料金を示す.

以下の数值例では, 通勤鉄道を対象とする過去の実証研 究 13) における混雑不効用関数の南海本線の推定值を用い $\eta=4.5$, 大阪市の地下鉄四つ橋線を対象とする費用構造 分析 ${ }^{14)}$ を参考に $\iota=3.1, \zeta=0.0008$ (円/分）と設定する. また, $c=10$ (円/分) , $N=40,000$ (人), $H=450$ (分), $A$ : 全通勤者が一斎始業のときの 1 通勤者あたりの 1 日の賃 金が20,000(円)になるように設定する。

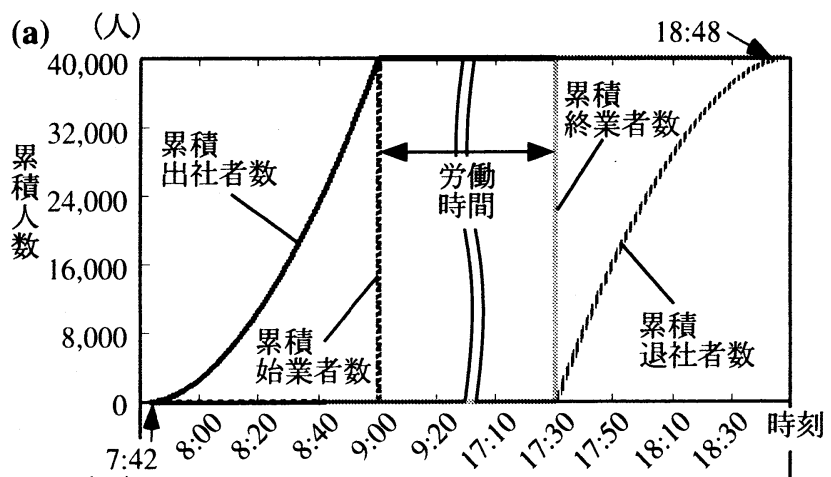

(b)

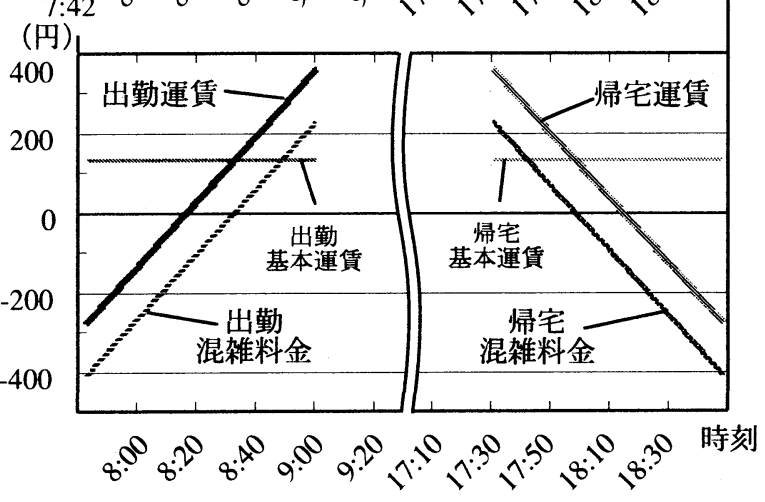

\section{図-1 全員が一斉始業・終業のパターンと混雑料金}

なお，結果の表示の便宜上，フレックスタイム導入前の 労働時間帯を 9:00-17:30(昼休憩 1 時間) とし, 各個人は慣 例的に 9:00 と 17:30 が最も望ましい始業, 終業時刻と考 えているとする.

\section{(a) 全員が一斉始業・終業の解}

図-1(a) は，すべての従業者が 9:00 始業，17:30 終業の 一斉始業・終業を行う解を表示したものである。このパ ターンは, 図-4に後述するようにパラメーータ $\alpha$ の設定に 関わらず，最適解になることはない.しかしながら， $\alpha$ が 1 に近い大きな值を取る時には, 最適なパターンとの効用 の差は小さく, 実際的には最適な状況と考えても差し支え ない。このパターンでは, 混雑を避けるために7時台から 出社する従業者が存在するが, $\alpha$ が大きいため, 出社直後 の $\rho(t)$ が小さい時間帯に始業しても得られる賃金が少な いため, 各従業者は全員が出社するのを待って始業する. 帰宅時も同様に全員の終業時にあわせて終業する.

図-1(b)は, 図-1(a)のパターンを実現するために必要な, 時刻毎の混雑料金を示したものである. 実際には, 基本運 賃と, 時刻毎に異なる混雑料金を合わせたものを運賃とし て徵収する。このパターンでは, 遅く出勤するほど列車の 混雑度が高く，遅い時間帯ほど高い混雑料金を課して，こ れを緩和することになる。結果として，一斉始業時刻であ る 9:00に出社する通勤者に最も高い混雑料金が課される. なお,この数值例では混雑料金の格差を大きくつける必要 があるため，8:16以前に出社する通勤者の運賃が負となっ た。つまり，早く出社する通勤者に報奖金等の報酬を与え ることが必要となる。

この数值例の 1 人当たりの平均効用は 19,000 円である (貢金:20,000 円, 往復スケジュールコスト:-554 円, 往復 


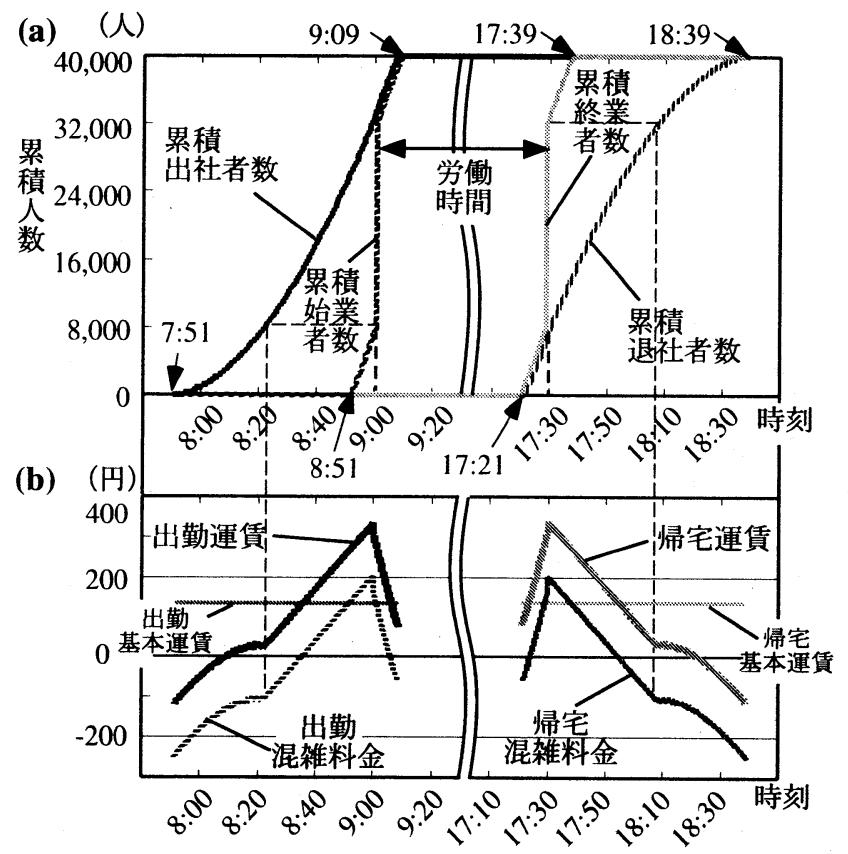

図 -2 混在パターンと混雑料金

混雑不効用:-182 円，往復運賃:264 円).

(b) フレックスと一齐始業・終業が混在する解

$\alpha$ を 0.5 に設定した上で数值計算を行うと図-2(a)のよ うな最適解が得られる。

この解では, 約 6 割の従業者が 9:00(17:30) に一斉始業 (終業)を行い, 残りの 4 割の従業者がその前後の 18 分間 に連続的に始業 (終業) するフレックスタイムを行う．出 勤・帰宅時の単位スケジュールコスト $c$, 弾力值のパラメー 夕 $\eta$ などに比べて， $\alpha$ がある程度小さいため, 混雑を避け るために出社 (退社) 時刻をずらしたり，待ち時間を減ら すために始業 (終業) 時刻をずらすことのメリットが貨金 の減少分を上回る従業者が存在する.

図-2(b) より，混雑料金は一斉始業時刻 (9:00) が最も高 い. 9:00 以降の通勤者は賃金の減少分が大きく，混雑料金 は安くなる．また，9:00 以前の通勤者は混雑度を緩和する ために, 早く出勤する通勤者ほど安い混雑料金となる。し かし，8:22 以前に出社し，9:00 以前に始業するフレック スタイム通勤者は午前の労働時間が長いことに起因する 賃金差が混雑料金に加えて作用するため，8:22 以前の混 雑料金の変化率が小さくなる.

このときの 1 人当たりの平均効用は 19,091 円である (賃 金:19,917 円，往復スケジュールコスト:-376 円，往復混 雑不効用:-183 円, 往復運賃:266 円).

この数值例の場合, フレックスタイムの導入が困難な企 業が存在しても，他の 4 割の通勤者にフレックスタイム制 度を導入することができれば, 最適な状況を作り出すこと が可能である。

\section{(c) 全員がフレックスタイムの解}

$\alpha$ を 0.2 に設定した上で数值計算を行うと, 図-3(a)の ような最適解が得られる。

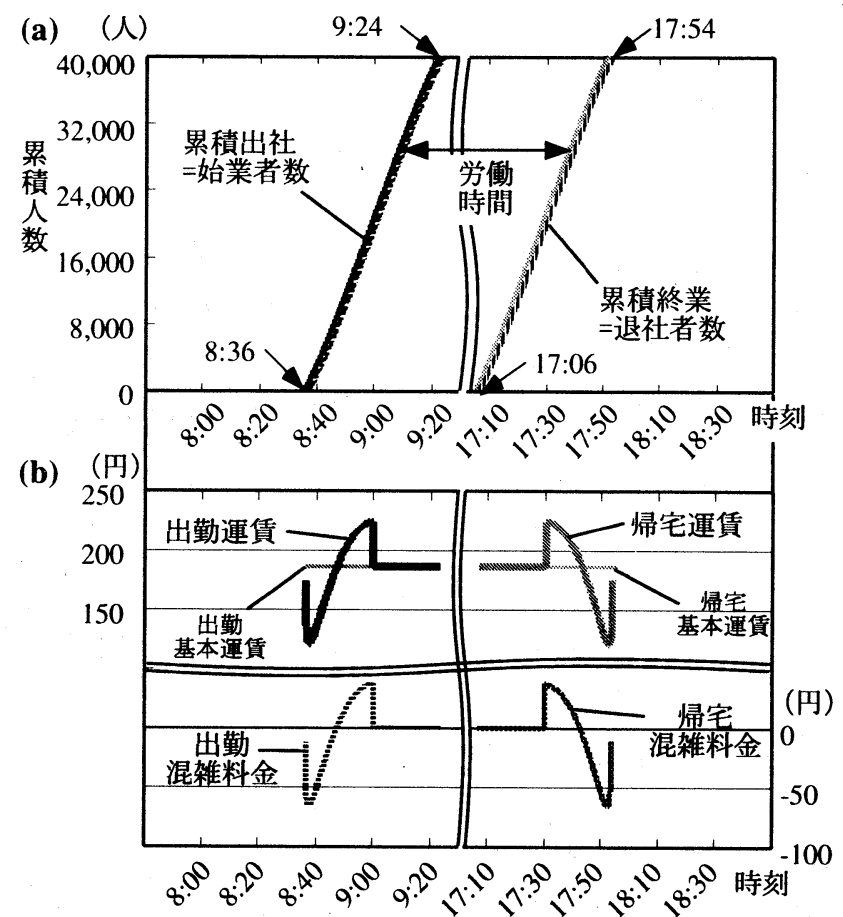

図 - 3 全員がフレックスタイムのパターンと混雑料金

この解では，全従業者が 8:36-9:24(17:06-17:54)の 48 分 間に連続的に始業(終業)するフレックスタイムを行う。こ のとき, 全従業者が出社と同時に始業し, 終業と同時に退 社する. $\alpha$ が小さく，労働時間帯を他の従業者とずらして も十分な賃金が得られる。そのため, 混雑を避けたり, 待 ち時間を減らすために出社，退社時刻を他の従業者とずら すことが有利となるパターンである。

全員が出社と同時に始業し，終業と同時に退社すること から，通勤者は出社順に退社する。そのため,このパター ンの混雑料金には様々な賦課方法が考えられる．図-3(b) に，時刻別混雑料金の一例を示す．混雑料金は最高の賃金 を得る 20,000 人目の通勤者が出社 (退社) する 9:00(17:30) が最も高い. 出社時刻が早くなるか, または退社時刻が遅 くなるほど得られる賃金が少ないため, 混雑料金は低くな る.ただし, 最早出社時刻, 最遅退社時刻付近では, 混雑 度が 0 に近くなるため, 等効用を満たすために混雑料金 が高く設定される。

このときの 1 人当たりの平均効用は 19,184 円である (賃 金:19,816 円，往復スケジュールコスト:0 円, 往復混雑不 効用: -258 円, 往復運賃:374 円).

この $\alpha=0.2$ のケースにおいて，最適解である上記の パターンを実現するためには全従業者にフレックスタイム 制度を導入する必要がある。もし、フレックスタイムを一 切認めずに，一斉始業を行わせるという条件で最適化する と, (a) と同じ効用が得られる。これと(c) の最適解を比較 すると，賃金は 180 円程度の減少でほとんど減らないが, 待ち時間がなくなるためスケジュールコストが 0 になり， 結果として効用は上回る。ただし, 運貨や混雑は悪化して いる。このことから，混雑を緩和することが必ずしも社会 全体の効用を最大化するわけではなく，都市ごとにその効 
(円）

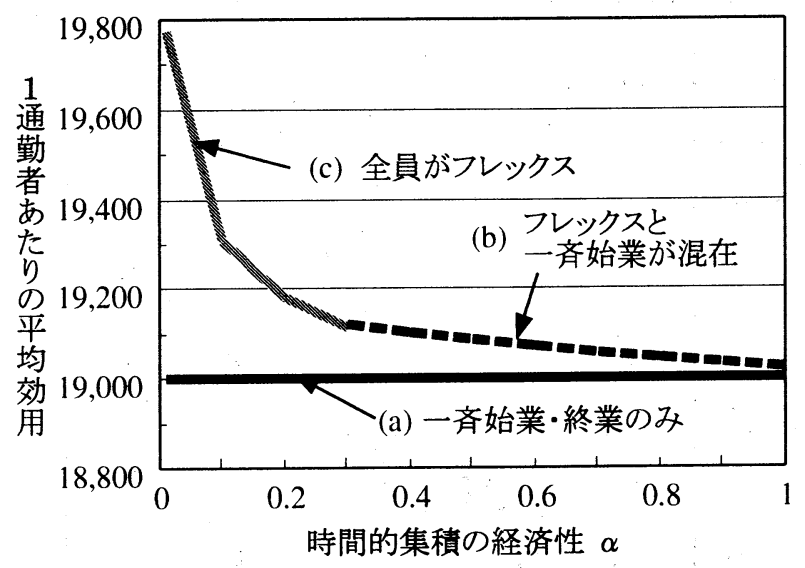

図-4 $\alpha$ の違いによる最適パターンと平均効用

果を吟味する必要があることを意味している。

\section{（2）時間的集積の経済性と最適パターン}

時間的集積の経済性の大きさを表す $\alpha$ の値を変化させ て, 数值計算を行った. 図-4 は, $\alpha$ の值に応じた最適なパ ターンと, そのときの 1 通勤者あたりの平均効用を表して いる，さらに，フレックスタイム制度の導入による効果を 見るために, フレックスタイムが導入されていない状況で あるパターン (a)の平均効用を併せて表記した。

$\alpha>0.28$ の時は, (b) フレックスと一斉始業が混在する パターンが最適となる。 (a) 一斉始業・終業のパターンと 比較すると, $\alpha$ の值に応じて, 100 円程度のフレックスタ イムによる効果があることが分かる。しかし， $\alpha$ が1に近 づくと, 差がわずかしかなくなり, フレックスタイム導入 の効果があまり期待できなくなる.

一方， $\alpha<0.28$ の時は, (c) 全員がフレックスのパター ンが最適となり, 効用も大きく増加し, フレックスタイム 導入の効果がある.

\section{(3) フレックスタイムの最適道入割合}

以上の数値計算例の最適パターンにおいて, 何割の通勤 者がフレックスタイムを行っているかを示したのが図-5で ある。

$\alpha>0.28$ の時, 最適パターンでは 2 割から 5 割の通勤者 がフレックスタイムを行う。つまり, 実際にフレックスタ イムを導入できない企業が存在しても， $\alpha$ の值に応じて， 2 割から 5 割の通勤者にフレックスタイムを導入できれば, 最適パターンを実現できる。一方， $\alpha<0.28$ の時は, 全 員がフレックスタイムを行わなければ，最適解を実現でき ない.

\section{6. おわりに}

本研究では，大都市の鉄道通勤に対する最適なフレック スタイムのパターンを理論的に分析できるモデルを構築 し, 求解した。ささらに, 数值例により, 最適な状況を作り

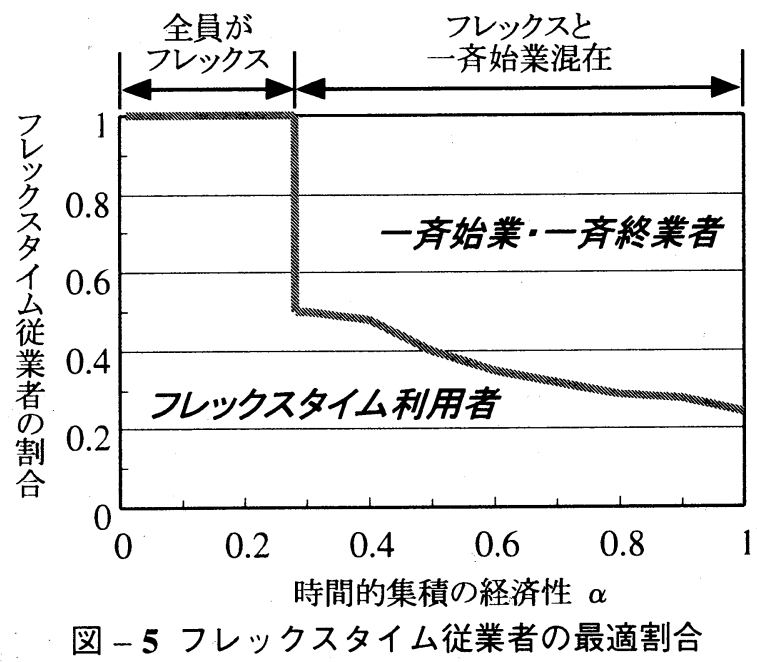

出すための時刻別混雑料金の值と，何割の従業者がフレッ クスタイムを行えばよいかを定量化できることを示した. また，効用の大きさも定量的に評価し，企業の生産性の低 下を考慮してもフレックスタイム制度の効果があることを 確認した.

本研究では，通勤者や企業を単一に仮定した。しかし， 実際の都市には嗜好の異なる通勤者や規模の異なる複数 の産業・職種が存在しており,これらを考慮する必要が ある。また，時刻別運賃といった手段を用いない状況下 で, 達成されるパターンの分析も必要である (利用者均衡 問題)。さらに，本研究で想定した時刻別運賃は連続的に 運賃を変化させているが，より現実的な多段階運賃シス テムのケース，あるいは運賃の代わりに始業時刻別に差 別化された事業所税の制度を導入するケースについて分 析を行う必要があると考える。

\section{参考文献}

1) 労働省政策調查部: 平成 11 年貨金労働時間制度等総合調査, 2000.

2）例えば，高山 純一・谷 英賢・木村 実・小村 正隆：金沢市 における時差出勤制度の社会実験, 土木計画学研究・論文集, No.15, pp.821-830, 1998.

3) Hall, R. : Booms and Recessions in a Noisy Economy, Yale Univ. Press, New Haven and London, 1991.

4) 吉村充功・奥村誠・塚井 誠人: 都市内業務トリップにおけ る時間的集積の経済性, 都市計画論文集, No.34, pp.217-222, 1999.

5) Henderson,J.V. : The economics of staggered work hours, Journal of Urban Economics, Vol.9, pp.349-364, 1981.

6) Henderson,J.V. : Economic Theory and the Cities, Academic Press, Chap.8, 1985 [折下功訳, 経済理論と都市, 勁草書房, 1987].

7）文世一・米川誠: フレックスタイム制が混雑に及はす影響, 応用地域学会発表論文, 1997.

8）赤松隆・早崎俊和・前田祐希：道路交通における通勤混雑緩 和のための最適勤務開始時刻分布, 土木計画学研究・論文集, No.16, pp.979-989, 1999.

9）奥村誠・永野光三・小林潔司: 始業時刻の設定が鉄道通勤交通 に及ほす影響に関する研究, 土木計画学研究・論文集, No.15, pp.831-840, 1998. 
10）永野光三·奥村誠·小林潔司 : 鉄道時差出勤の導入インセンテ イブに関する分析, 土木計画学研究·講演集, No.21(2),pp.885888,1998 .

11）吉村充功・奥村誠：鉄道通勤に扔ける「スーパーフレック ス」制度の経済評価, 都市計画論文集, No.35, pp.1075-1080, 2000.

12) 志水 清孝: 最適制御の理論と計算法, コロナ社, pp.54-104, 1994.

13）志田州弘・古川敦・赤松 隆 ·家田仁: 通勤鉄道利用者の 不効用関数パラメータの移転性に関する研究, 土木計画学研 究・講演集, No.12, pp.519-525, 1989.

14）永野光三：大都市圈における鉄道通勤交通のマネジメント 施策に関する研究, 京都大学博士論文, pp.173-176, 1998.

\section{付録 A 最適始業時刻分布決定問題の解}

状態制約付き最適制御問題の最適性条件 12) より, 最適 始業時刻分布決定問題 (17a)-(17p) を求解すると, 状態制 約 (17g)-(17j) が0 か否かの組み合わせにより，3つのパ ターンが最適軌道の必要条件を満たし, 解が解析的に求 まる。

\section{(1) 全員が一斉始業・終業の解}

出勤時間帯 $t \in\left[T_{0}, T_{2}\right]$ の時刻別混雑度 $s(t)$, 時刻別輸 送力 $u(t)$, 累積出社者率 $m(t)$ は次式で表される.

$$
\begin{aligned}
s(t) & =\left(\frac{c\left(t-T_{0}\right)}{1+\eta}\right)^{\frac{1}{\eta}} \\
u(t) & =\left(\frac{\eta}{\zeta \iota}\right)^{\frac{1}{\theta}}\left(\frac{c\left(t-T_{0}\right)}{1+\eta}\right)^{\frac{1+\eta}{\eta \theta}} \\
m(t) & =\frac{\zeta \theta}{c N}\left(\frac{\eta}{\zeta \iota}\right)^{\frac{1+\theta}{\theta}}\left(\frac{c\left(t-T_{0}\right)}{1+\eta}\right)^{\phi} \\
r(t) & =v(t)=l(t)=n(t)=0
\end{aligned}
$$

ここで, $\theta=\iota-1, \phi=(1+\eta)(1+\theta) /(\eta \theta)$ である. 出社す る通勤者が存在する時間帯 $\left(T_{2}-T_{0}\right)$ は次式で表される。

$$
T_{2}-T_{0}=(\phi N)^{\frac{1}{\phi}}\left(\frac{\zeta \iota}{\eta}\right)^{\frac{1}{\theta \phi}}\left(\frac{1+\eta}{c}\right)^{\frac{\phi-1}{\phi}}
$$

帰宅時間帯 $t \in\left[T_{1}, T_{3}\right]$ の時刻別混雑度 $r(t)$, 時刻別輸 送力 $v(t)$, 累積退社者率 $l(t)$ は次式で表される.

$$
\begin{aligned}
& r(t)=\left(\frac{c\left(T_{3}-t\right)}{1+\eta}\right)^{\frac{1}{\eta}} \\
& v(t)=\left(\frac{\eta}{\zeta \iota}\right)^{\frac{1}{\theta}}\left(\frac{c\left(T_{3}-t\right)}{1+\eta}\right)^{\frac{1+\eta}{\eta \theta}} \\
& l(t)=1-\frac{\zeta \theta}{c N}\left(\frac{\eta}{\zeta \iota}\right)^{\frac{1+\theta}{\theta}}\left(\frac{c\left(T_{3}-t\right)}{1+\eta}\right)^{\phi} \\
& s(t)=u(t)=0, \quad m(t)=n(t)=1
\end{aligned}
$$

退社する通勤者が存在する時間帯 $\left(T_{3}-T_{1}\right)$ は次式で表さ れる。

$$
T_{3}-T_{1}=(\phi N)^{\frac{1}{\phi}}\left(\frac{\zeta \iota}{\eta}\right)^{\frac{1}{\phi \phi}}\left(\frac{1+\eta}{c}\right)^{\frac{\phi-1}{\phi}}
$$

本パターンでも明らかなように, 本研究の設定では, 出 勤時と帰宅時の時間価值を等しくおいていることから, 最 適解のパターンは, 時刻 $\left(T_{0}+T_{3}\right) / 2$, 累積通勤者割合 0.5 の交点に対し点対称である. 以下, $t \in\left[\left(T_{0}+T_{3}\right) / 2, T_{3}\right]$ の 区間の解の記述を省略し, $t \in\left[T_{0},\left(T_{0}+T_{3}\right) / 2\right]$ の区間につ いてのみ，記述する。

\section{（2）フレックスタイムと一斉始業・終業が混在の解}

時刻 $t \in\left[T_{0}, T_{1}\right]$ の区間は，先に示した式 (18)-(21) であ る. 時刻 $t \in\left[T_{1},\left(T_{0}+T_{3}\right) / 2\right]$ において, $s(t), u(t), m(t)$ は, 先の式 (18)-(20) と同様である. $l(t)(=n(t))$ は, 次の 2 元連立微分方程式の解として求まる。

$$
\begin{aligned}
\dot{l}(t) & =\frac{1}{N}\left(\frac{\eta}{\zeta \iota}\right)^{\frac{1}{\theta}}\left(\frac{-\xi_{0} c t-\xi_{b_{1} 2} / N-\beta_{2 b_{1}}(t) / N}{\xi_{0}(1+\eta)}\right)^{\phi-1}(28) \\
\dot{\beta}_{2 b_{1}}(t) & =\xi_{0} A N^{\alpha}\left[\left\{(1+\alpha) n(t) N+\xi_{b_{1} 4} \alpha\right\} n(t)^{\alpha-1}\right. \\
& \left.-\left\{(1-(1+\alpha) n(t)) N-\xi_{b_{1} 4} \alpha\right\}(1-n(t))^{\alpha-1}\right](29)
\end{aligned}
$$

ただし， $\xi_{b_{1} 2}, \xi_{b_{1} 4}$ はそれぞれ状態拘束式 $(17 \mathrm{c}),(17 \mathrm{e})$ に対 応する区分的に連続なべクトル値関数の積分定数であり, 最適性条件より求まる。 $\beta_{2 b_{1}}(t)$ は状態制約式 $(17 \mathrm{~h})$ に対応 するスカラー值関数である。このときの $r(t), v(t)$ は次式 の通りである。

$$
\begin{aligned}
& r(t)=\left(\frac{-\xi_{0} c t-\xi_{b_{1} 2} / N-\beta_{2 b_{1}}(t) / N}{\xi_{0}(1+\eta)}\right)^{\frac{1}{\eta}} \\
& v(t)=\left(\frac{\eta}{\zeta \iota}\right)^{\frac{1}{\theta}}\left(\frac{-\xi_{0} c t-\xi_{b_{1} 2} / N-\beta_{2 b_{1}}(t) / N}{\xi_{0}(1+\eta)}\right)^{\frac{1+\eta}{\eta \theta}}
\end{aligned}
$$

\section{(3) 全員がフレックスタイムの解}

時刻 $t \in\left[T_{0}, T_{3}\right]$ の $m(t)(=n(t)=l(t))$ は, 以下の 2 元連 立微分方程式の解として求まる.

$$
\begin{aligned}
\dot{m}(t) & =\frac{1}{N}\left(\frac{\eta}{\zeta \iota}\right)^{\frac{1}{\theta}}\left(\frac{\xi_{0} c t-\xi_{b_{2} 1} / N+\beta_{3 b_{2}}(t) / N}{\xi_{0}(1+\eta)}\right)^{\phi-1} \\
\dot{\beta}_{3 b_{2}}(t) & =-\xi_{0} c N \\
& -\frac{1}{2} \xi_{0} A\left[\left\{(1+\alpha) n(t) N+\xi_{b_{2} 4} \alpha\right\} n(t)^{\alpha-1} N^{\alpha}\right. \\
& \left.-\left\{1-(1+\alpha) n(t) N-\xi_{b_{2} 4} \alpha\right\}(1-n(t))^{\alpha-1} N^{\alpha}\right]
\end{aligned}
$$

$\xi_{b_{2} 1}, \xi_{b_{2} 4}$ はそれぞれ状態拘束式 (17b), (17e) に対応する区 分的に連続なべクトル值関数の積分定数であり, 最適性条 件より求まる。 $\beta_{3 b_{2}}(t)$ は状態制約式 (17i) に対応するスカ ラー值関数である。

$s(t)(=r(t)), u(t)(=v(t))$ は次式の通りである.

$$
\begin{aligned}
& s(t)=\left(\frac{\xi_{0} c t-\xi_{b_{2} 1} / N+\beta_{3 b_{2}}(t) / N}{\xi_{0}(1+\eta)}\right)^{\frac{1}{\eta}} \\
& u(t)=\left(\frac{\eta}{\zeta \iota}\right)^{\frac{1}{\theta}}\left(\frac{\xi_{0} c t-\xi_{b_{2} 1} / N+\beta_{3 b_{2}}(t) / N}{\xi_{0}(1+\eta)}\right)^{\frac{1+\eta}{\eta \theta}}
\end{aligned}
$$


近年, フレックスタイムなどの TDM 施策が実施され，行政サイドでも制度の導入促進を提唱している。し かし, 実際にどの程度まで導入割合が増えれば社会的に十分なのかどうかはこれまで明らかにされていない． 本研究では，大都市の鉄道通勤を対象に通勤者や企業といったそれぞれの主体の効用を定式化し，フレック スタイム下の社会的に最適な出社・始業・終業・退社時刻分布を解析的に求めた。さらに, 数值例を通して, 最適パターンを実現するための時刻別運賃の設定值と, 何割の従業者がフレックスタイムを行えば社会的に 最適な状況を作り出すことが可能であるかを示した．また，実際に享受する効用の大きさも明らかにした。

\section{Study of Patterns for Optimal Flexible Work Hours on Railway Commuting*}

By Mitsunori YOSHIMURA ${ }^{\dagger}$ and Makoto OKUMURA ${ }^{\ddagger}$

In this paper, we proposed the model to analyze the optimal commuting and work start (end) time distribution under flexible work hours on railway commuting considering temporal agglomeration effect. Based on optimal control theory, we could solve our model analytically, and get three optimal patterns. Through numerical examples, we could calculate values of differentiated fare in time and introduction rate of flexible workers in order to realize the optimum situation. Furthermore, we could calculate utility level for each pattern, and evaluate economic effect of the flexible work hours. 